\title{
Membangun Model Bisnis Pada Mutiara Seragam Online Dengan Pendekatan Business Model Canvas
}

\author{
Yudi Santoso ${ }^{1}$, Nurwati ${ }^{2}$ \\ ${ }^{1,2}$ Program Studi Sistem Informasi Fakultas Teknologi Informasi Universitas Budi Luhur \\ Email: ${ }^{1}$ yudi.santoso@budiluhur.ac.id, ${ }^{2}$ nurwati@budiluhur.ac.id
}

\begin{abstract}
Abstrak
Pengembangan media online untuk penjualan sangat dibutuhkan dalam menyiapkan persaingan di pasar online. Website penjualan harus dikelola dengan bisnis model yang mengadopsi Business Model Canvas (BMC) sebagai salah satu strategi pemasaran online. Adapun blok-blok yang ada di Business Model Canvas (BMC) dapat menampung kebutuhan customer dalam pemenuhan pesanan seragam sekolah. Value dari model bisnis ini adalah customer dapat melihat track/jejak pesanannya pada website sehingga memberikan jaminan pesanan seperti terlihat pada halaman activity produksi. Kemudian customer diberikan service untuk kemudahan komplain barang dan informasi harga barang yang terbaru seperti yang terdapat pada halaman service. Tujuannya adalah membangun model bisnis pada Mutiara Seragam Online sehingga pendapatan penjualan mengalami peningkatan.

Kata kunci: Business Model Canvas (BMC), model bisnis, penjualan online, value
\end{abstract}

\section{Abstract}

The development of online media for sales is needed in preparing for competition in the online market. The sales website must be managed with a business model that adopts the Business Model Canvas $(B M C)$ as an online marketing strategy. The blocks in the Business Model Canvas (BMC) can accommodate customer needs in fulfilling school uniform orders. The value of this business model is that the customer can see the track/trace of his order on the website so as to provide a guaranteed order as shown on the production activity page. Then the customer is given service for the convenience of goods complaints and the latest information on the price of goods as found on the service page. The goal is to build a business model on Mutiara Uniform Online so that sales revenue increases.

Keywords : Business Model Canvas (BMC), business model, online sales, value

\section{PENDAHULUAN}

Saat pandemi seperti ini, media online dibutuhkan untuk mengurangi kerumunan dan menjaga jarak fisik sehinga penyebaran virus covid19 dapat dicegah sedini mungkin. Dengan pengertian media online secara umum ini, maka email, mailing list (milis), website, blog, whatsapp, dan media sosial (sosial media) masuk dalam kategori media online [1].

Penggunaan internet untuk aktivitas transaksi bisnis dikenal dengan istilah Electronic Commerce (E- Commerce). Penggunaan internet untuk transaksi bisnis sudah dianggap sebagai suatu hal yang penting, hal ini ditandai dengan meningkatnya jumlah pengusaha yang menggunakan ecommerce dalam perusahaannya. E-commerce didefinisikan sebagai proses pembelian, penjualan, mentransfer atau bertukar produk, jasa atau informasi melalui jaringan komputer melalui Internet [1] dan perdagangan elektronik atau yang lebih dikenal dengan e-commerce di Indonesia kini sedang hangat-hangatnya. Banyak pelaku di bidang ini yang bermunculan untuk memanfaatkan potensi jumlah penduduk Indonesia yang banyak. Selain itu, tingkat kesadaran konsumen terhadap e-commerce juga terus meningkat dengan mulai mengadopsi kebiasaan berbelanja online. Agustin menyatakan [2] bahwa BMI Research mencatat bahwa rata-rata pengeluaran belanja online orang Indonesia dalam setahun mencapai $\mathrm{Rp} 825.000$ per orang. Tahun lalu saja, nilai transaksi belanja online orang Indonesia mencapai Rp 21 triliun. Angka ini diproyeksi akan meningkat signifikan di tahun 2015, yakni hingga mencapai Rp 50 triliun atau meningkat lebih dari dua kali lipat.

E-Commerce B2B-B2C adalah jenis E-Commerce dengan bentuk interaksi Bussiness to Bussiness (B2B) dan Bussiness to Customer (B2C) dimana terjadi interaksi antara produsen ( perusahaan, industri rumah tangga, penyedia barang dan jasa) dengan distributor dan pengecer, yang kemudian dilanjutkan oleh distributor dan pengecer ke konsumen berbasiskan media elektronik yang 
terhubung ke jaringan internet. Dengan begitu terdapat Manufacturing Supply Chain yang terdiri dari Manufacturer (M), Supplier (S) dan Customer (C) pada E- Commerce sehingga tidak sekedar antara penjual dan pembeli [2].

Mutiara seragam online sebagai toko seragam sekolah online memiliki tujuan untuk untuk meraih keuntungan, telah menetapkan bahwa bisnis penjualan seragam sekolah memepunyai peluang yang besar di penjualan online. Namun, kondisi saat ini belum signifikan jika dilihat dari hasil pendapatan penjualan Mutiara Seragam secara keseluruhan.

Untuk mengembangkan pemasaran pada Mutiara Seragam yang bergerak pada penjualan seragam sekolah online maka diperlukan strategi atau pemetaan promosi pemasaran melalui ecommerce dengan menggunakan pendekatan Business Model Canvas (BMC).

Model bisnis (BMC) menggambarkan strategi bisnis yang berfokus pada operasi utama (key activity), mitra utama (key partners), aliran pendapatan (revenue stream), proposisi nilai (value proposition), hubungan pelanggan (customer relationship), segmen basis pelanggan (customer segments), struktur biaya (cost structure), elemen kunci dari bisnis utama (key resources), Sumber daya saluran (channels). BMC digunakan oleh startup dan organisasi bisnis untuk mendapatkan gambaran lengkap dalam menganalisis model bisnis mereka [3].

Beberapa peneliti telah melakukan penelitian mengenai pengembangan e-commerce menggunakan pendekatan Business Model Canvas untuk berbagai keperluan, antara lain untuk strategi pengembangan bisnis cargo PT. Garuda Indonesia, TBK [4], analisa usaha mikro [5], analisis bisnis cenderamata dan jasa perjalanan wisata [6] dan mendatangkan para pelanggan baru serta memudahkan para pelanggan [7], dan lain-lain. Tabel 1 menyajikan rangkuman beberapa penelitian terkini yang memanfaatkan e-commerce menggunakan pendekatan Business Model Canvas.

Tabel 1 Penelitian terkait memanfaatkan e-commerce menggunakan pendekatan Business Model

Canvas

\begin{tabular}{lll}
\hline Paper & Tujuan penelitian & Hasil penelitian \\
\hline [4] & Menganalisis kondisi Direktorat Cargo & Hasil dari identifkasi awal dari 9 \\
dengan menggunakan Business model & elemen blok BMC Direktorat Cargo \\
canvas (BMC) dan membuat New BMC & disertai analisis tingkat kepentingan \\
Direktorat Cargo PT. Garuda Indonesia, & dan kinerja terdapat tiga elemen blok \\
Tbk. Alat analisis yang digunakan dalam & prioritas yang perlu dilakukan \\
penelitian ini adalah BMC, importance & perbaikan, yaitu customer segment, \\
and performance analysis (IPA), dan five & channel, dan revenue streams. five \\
forces porter sehingga dapat menyusun & forces porter analysis dan Industry \\
strategi pengembangan bisnis cargo PT. & foresight pada industri Cargo \\
Garuda Indonesia, TBK & menjadi masukan pada perbaikan 3 \\
& elemen blok. Perubahan elemen \\
& customer segmen, yaitu target pasar \\
& menjadi lebih luas dari customer port \\
to port menjadi customer door to \\
door. Perubahan pada elemen \\
channel, yaitu pengembangan dengan \\
memperbanyak pembukaan channel \\
baru seperti gerai, sales outlet, booth, \\
small counter. Pengembangan pada \\
revenue stream, yaitu adanya \\
pendapatan tambahan dari door to \\
door, fee based income dan revenue \\
sharing dari sinergi BUMN. Selain \\
itu perubahan pada ketiga elemen \\
tersebut juga menyebabkan \\
pengembangan pada elemen value \\
Preposition, Customer Relationship, \\
Key Patners, Key Activities serta \\
pada elemen Key resource dan cost
\end{tabular}




\begin{tabular}{|c|c|c|}
\hline & & $\begin{array}{l}\text { Structure agar dapat dioptimalkan } \\
\text { dan efisiensi sehingga menciptakan } \\
\text { new BMC yang bermanfaat bagi } \\
\text { pengembangan perusahaan yang } \\
\text { sesuai perkembangan industri. }\end{array}$ \\
\hline [5] & $\begin{array}{l}\text { Menganalisis kekuatan, kelemahan, } \\
\text { peluang, dan ancaman berdasarkan } 9 \\
\text { elemen Bisnis Model Kanvas dan } \\
\text { memetakan strategi-strategi baru dalam } \\
\text { rangka meningkatkan penjualan produk }\end{array}$ & $\begin{array}{l}\text { Dari hasil akhir pemetaan BMK } \\
\text { menunjukkan beberapa tambahan } \\
\text { strategi pada elemen-elemen yang } \\
\text { dapat dijadikan alternatif strategi } \\
\text { baru untuk diterapkan. Elemen- } \\
\text { elemen tersebut antara lain: elemen } \\
\text { Proposisi Nilai, Saluran, Hubungan } \\
\text { dengan Pelanggan, Sumber Daya } \\
\text { Utama, dan Struktur Biaya. }\end{array}$ \\
\hline [6] & $\begin{array}{l}\text { Menganalisis proses bisnis cenderamata } \\
\text { dan jasa perjalanan wisata yang } \\
\text { dilakukan secara konvensional } \\
\text { menggunakan Business Model Canvas } \\
\text { (BMC) untuk mengetahui kelebihan, } \\
\text { kelemahan, ancaman dan peluang. } \\
\text { Kemudian mengidentifikasi dan } \\
\text { menganalisis aspek Performance, } \\
\text { Information, Economic, Control, } \\
\text { Efficiency, and Services (PIECES) pada } \\
\text { usaha cenderamata dan jasa perjalanan } \\
\text { wisata yang telah mengadopsi konsep e- } \\
\text { commerce. }\end{array}$ & $\begin{array}{l}\text { Adopsi teknologi informasi dapat } \\
\text { mendukung operasional UMKM } \\
\text { dalam mereduksi biaya pemasaran } \\
\text { serta memberikan kemudahan dalam } \\
\text { hal transaksi maupun komunikasi } \\
\text { melalui platform digital. Adopsi } \\
\text { konsep e-commerce melalui aplikasi } \\
\text { WordPress, khususnya penggunaan } \\
\text { plugin WooCommerce dan 3CX Live } \\
\text { Chat dalam website CV. Xindotour } \\
\text { telah memudahkan proses transaksi } \\
\text { dan komunikasi antara penjual dan } \\
\text { konsumen. }\end{array}$ \\
\hline [7] & $\begin{array}{l}\text { Toko online diharapkan dapat } \\
\text { mendatangkan para pelanggan baru serta } \\
\text { memudahkan para pelanggan untuk } \\
\text { mendapatkan produk dari Konveksi } \\
\text { Gamis Tawakal. Dan dengan adanya } \\
\text { media pemasaran melalui instagram dan } \\
\text { facebook diharapkan dapat memudahkan } \\
\text { pelanggan untuk mendapatkan informasi } \\
\text { mengenai produk dari Konveksi Gamis } \\
\text { Tawakal. }\end{array}$ & $\begin{array}{l}\text { Menghasilkan sebuah sistem } \\
\text { penjualan online yang menjual } \\
\text { berbagai gamis pria, yang disajikan } \\
\text { dengan tampilan website penjualan } \\
\text { online yang menarik untuk } \\
\text { mempermudah customer dalam } \\
\text { melakukan pembelanjaan serta } \\
\text { pembayaran online dengan } \\
\text { menggunakan CMS WordPress serta } \\
\text { menambah jangkauan pelanggan } \\
\text { dari berbagai daerah. }\end{array}$ \\
\hline
\end{tabular}

\section{METODA PENELITIAN}

Penelitian ini menggunakan metode penelitian kualitatif deskriptif melalui pendekatan studi kasus pada Mutiara Seragam online yaitu toko online dengan usaha penjualan seragam sekolah yang beroperasi di Pondok Aren, Tangerang Selatan, Indonesia. Teknik pengambilan data menggunakan wawancara, observasi, dan studi literatur. Wawancara dilakukan kepada pemilik Mutiara Seragam Online untuk mendapatkan informasi utama. Observasi dilakukan untuk mengamati proses bisnis dan mengidentifikasi kendala operasi bisnis pada Mutiara Seragam Online. Adapun studi literatur dilakukan untuk mendapatkan sumber bacaan mengenai konsep Business Model Canvas (BMC) dan teori pendukung lainnya yang relevan dengan analisis penelitian ini.

Tahapan penelitian ini dimulai dengan merumuskan masalah dengan mengidentifikasi apa saja yang menjadi hambatan atau kendala pada Mutiara Seragam online. Adapun rumusan masalahnya adalah membangun bisnis model pada Mutiara Seragam Online dengan menggunakan Business Model Canvas (BMC). Tahapan selanjutnya dengan pengambilan data melalui wawancara dengan pemilik, 
observasi dan studi literatur. Target akhirnya adalah luaran hasil penelitian yaitu model bisnis pada Mutiara Seragam Online berupa website, seperti terlihat pada gambar 1 tahapan penelitian di bawah ini,

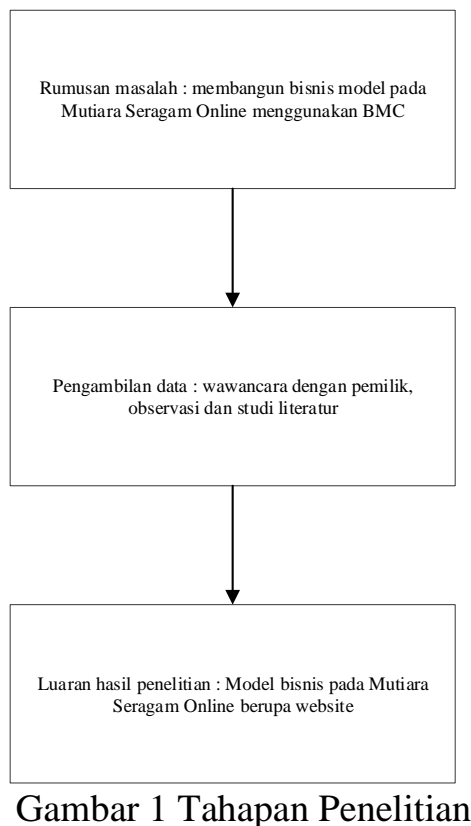

Adapun informasi yang diperoleh terkait dengan key partners, key activities, key resources, value propositions, customer relationships, customer segments, channels, cost structure, revenue stream yang diperoleh dari tahapan penelitian ini berguna untuk membangun Business Model Canvas (BMC) dengan usaha penjualan online pada Mutiara Seragam Online.

\section{HASIL DAN PEMBAHASAN}

\subsection{Identifikasi elemen Business Model Canvas Mutiara Seragam Online}

Proses bisnis usaha dapat dianalisis menggunakan Business Model Canvas (BMC) [8]. Pada model BMC ini, pemilik Mutiara Seragam Online dapat melihat keuntungan yang didapat dengan menggabungkan kriteria dengan key partners, key activities, key resources, value propositions, customer relationships, customer segments, channels, cost structure dan revenue stream.

3.1.1. Customer segment

Customer segment yaitu menentukan segmen target customer dari bisnis yang akan dikembangkan. Posisikandiri pada sisi customer untuk memperhatikan apa yang dilihat, didengar, dipikirkan dan dilakukan, menjadi keinginan dan tujuan, rasa takut, dan harapan [9]. Kriteria ini ditargetkan kepada toko seragam sekolah dan sekolah.

\subsubsection{Value Proposition}

Value proposition yaitu memperkirakan kebutuhan customer yang sudah diidentifikasi pada customer segment [9].

Nilai pertama pada elemen ini adalah tepat waktu yakni setiap pekerjaan yang akan dimulai di sepakati terlebih dahulu waktu pengerjaan hingga selesai pekerjaan tersebut. Nilai ke dua adalah harga yaitu harga yang diberikan adalah harga grosir sehingga toko sebagai reseller bisa bersaing harganya dibandingkan dengan toko lain. Nilai ke tiga adalah kualitas produk yaitu meskipun harga murah namun Mutiara Seragam Online tetap menjaga kualitas produk dengan standar grosir. Nilai ke empat adalah kualitas bahan yaitu bahan yang digunakan sesuai dengan permintaan pembeli/pasar.

\subsubsection{Channels}

Channels yaitu cara untuk mencapai customer [9]. Pada elemen ini Mutiara Seragam Online menggunakan domain www.nurwati.com ditambah kekuatan Search Engine Optimation (SEO) untuk memberikan informasi kepada user yang membutuhkan. Kemudian ditambah dengan media online facebook dan instagram.

3.1.4. Customer relationship 
Customer relationship yaitu mendefinisikan hubungan antara perusahaan dan customer [9]. Pada elemen ini Mutiara Seragam Online memberikan diskon pengiriman ke seluruh Indonesia, kemudahan komplain barang dengan penanganan yang baik dan kemudahan konsultasi kepada customer serta informasi daftar harga secara periodik.

\subsubsection{Revenue stream}

Revenue stream yaitu representasi dari jalur penerimaan uang yang akan diterima dari setiap customer segment [9]. Penerimaan Mutiara Seragam Online berasal dari penjualan seragam sekolah sebagai sumber utama, sehingga pendapatan Mutiara Seragam Online sangat bergantung dari banyaknya penjualan pertahun melalui online.

3.1.6. Key resources

Key resource adalah sumber daya utama yang menjelaskan mengenai aset terpenting yang diperlukan dalam membuat model bisnis kerja. Setiap model bisnis memerlukan sumber daya utama [9]. Resources ini berisi kontrol stok barang, pengelolaan bahan dan monitoring SEO di web page.

\subsubsection{Key activities}

Key Activities adalah kegiatan utama yang menjelaskan hal terpenting yaitu perusahaan harus membuat model bisnis [9]. Kegiatannya berisi tentang pencatatan penerimaan PO, pengadaan bahan sesuai kebutuhan, pemesanan ke konveksi untuk produk yang diperlukan, dan monitoring produksi.

\subsubsection{Key partnership}

Key partners adalah kunci kemitraan yang menjelaskan jaringan pemasok dan mitra yang membuat pekerjaan model bisnis [9]. Kriteria key partnership yaitu konveksi seragam sekolah, konveksi topi dan dasi, toko bahan, digital marketer dan kerjasama dengan agen pengiriman.

\subsection{9. $\quad$ Cost structure}

Cost Structure adalah struktur biaya yang menggambarkan semua biaya yang dikeluarkan dalam mengoperasikan model bisnis ini [9]. Adapun yang termasuk dalam cost structure adalah biaya google adwords, biaya domain, biaya pendukung untuk tenaga pendukung.

Business Model Canvas yang terbentuk untuk Mutiara Seragam Online terlihat pada gambar 2 dibawah ini,

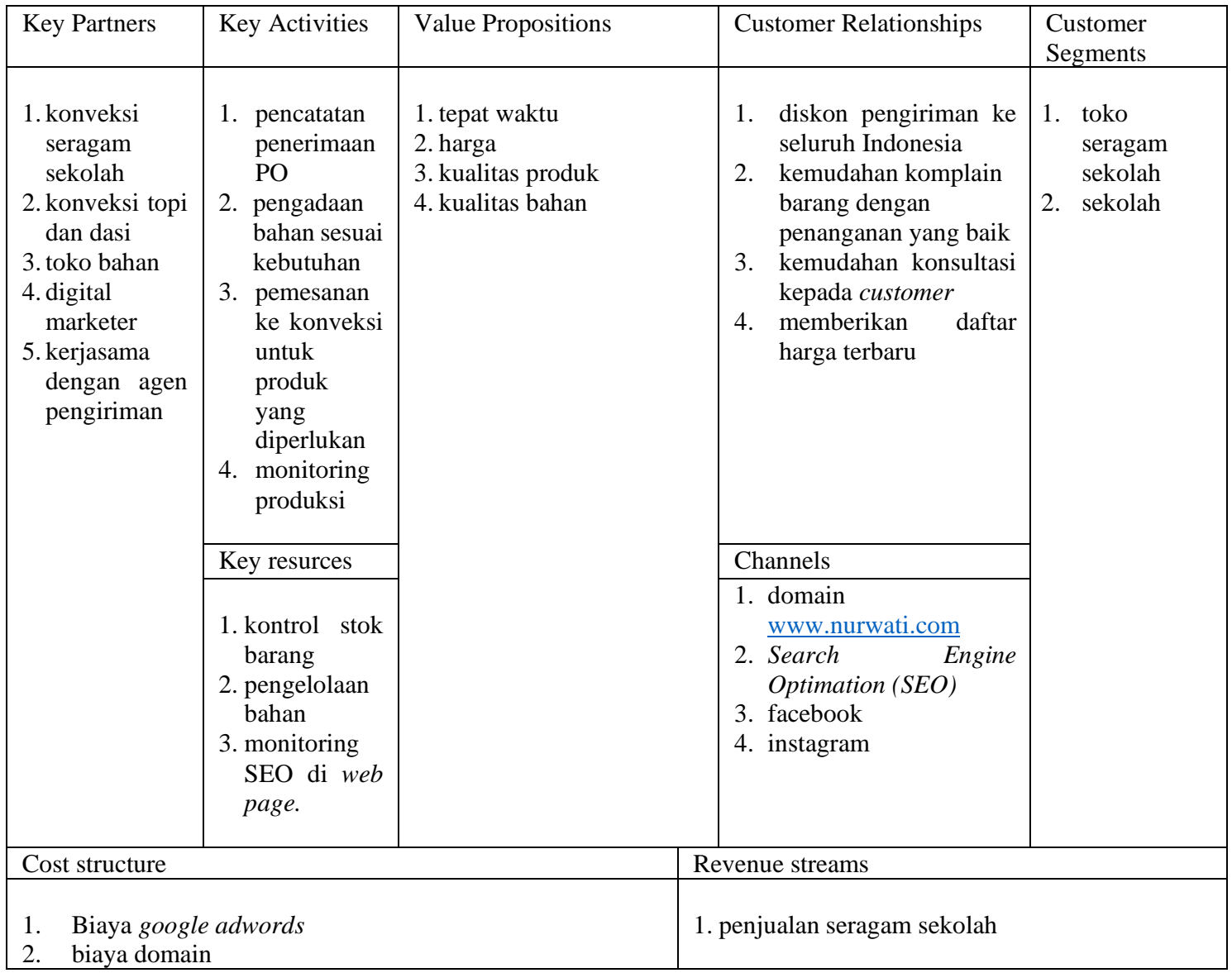


3. biaya pendukung untuk tenaga pendukung

\section{Gambar 2 Business Model Canvas Pas Mutiara Seragam Online}

3.2. Prototype desain web untuk Mutiara Seragam Online

3.2.1. Halaman home

Pada halaman home di https://nurwati.com berisi tentang informasi yang terkait mengenai Mutiara Seragam online. Di menu header ada logo Mutiara Seragam online, menu utama yaitu home, our clients, produk, galery, desain, service, activity produk dan about us. Pada halaman home ini juga berisi informasi usaha/kegiatan Mutiara Seragam online dan berapa lama sudah bergelut dalam penjualan seragam sekolah. Tidak lupa menampilkan nomor telepon yang bisa dihubungi dan google maps jika customer hendak mengunjungi toko Mutiara Seragam, seperti terlihat di gambar 3 halaman home di bawah ini;

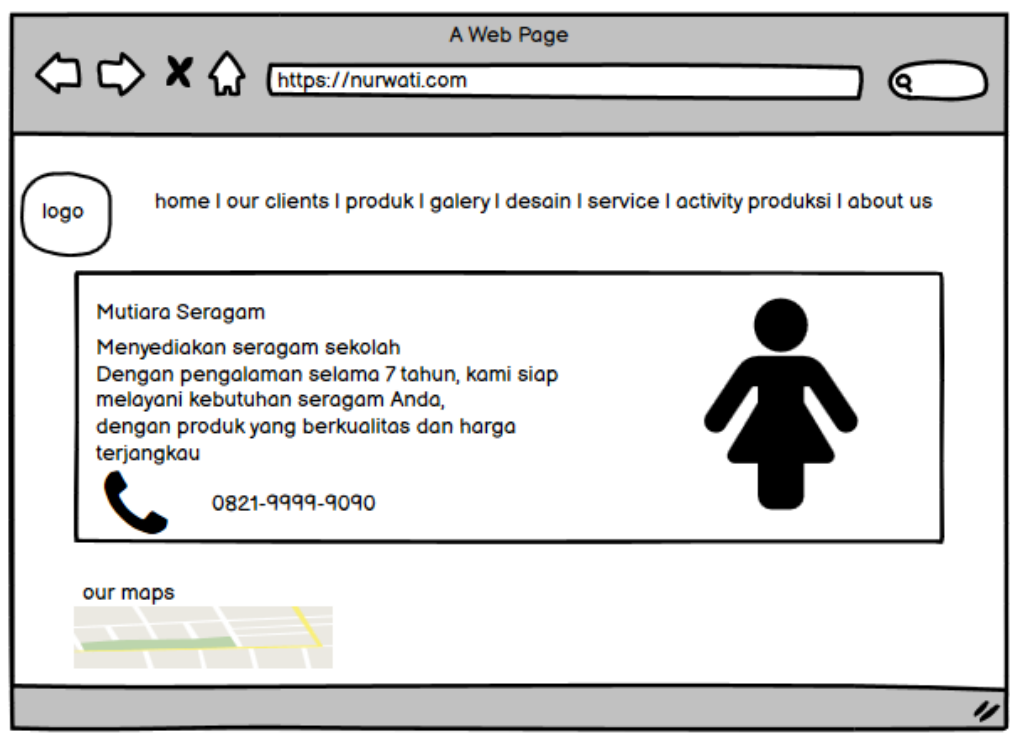

Gambar 3 halaman home

\subsubsection{Halaman our clients}

Halaman our clients berisi informasi mengenai siapa saja rekanan yang telah bekerja sama dengan Mutiara Seragam online. Rekanan ini adalah toko seragam sekolah dari pelbagai daerah di seluruh Indonesia dan hingga saat ini masih terus berjalan kerjasamanya. Selain toko seragam sekolah yang menjadi rekanan ada juga sekolah-sekolah yang menjalin kerjasama untuk memenuhi kebutuhan produk seragam sekolah misalnya dasi dan topi sekolah. Desain prototype dapat dilihat pada gambar 4 halaman our clients dibawah ini;

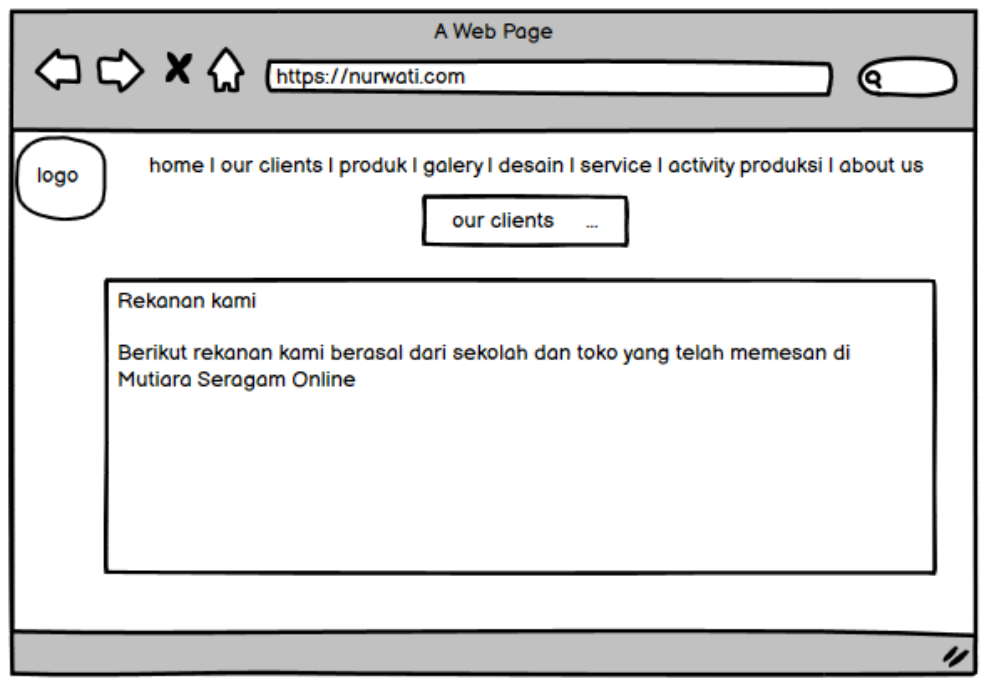




\section{Gambar 4 halaman our clients}

\subsubsection{Halaman activity produksi}

Pada halaman activity produksi menjelaskan tahapan-tahapan produksi terdiri dari pencatatan penerimaan po beserta tanggal, pembayaran dp beserta tanggal, pengadaaan bahan sesuai kebutuhan beserta tanggal, potong dan jahit beserta tanggal, pelunasan beserta tanggal dan pengiriman produk ke pelanggan beserta tanggal. Di setiap activity produksi ada tanggal dimulai kegiatan produksi. Jika tanggal acticity kosong menggambarkan kegiatan belum dimulai. Jadi customer dapat melihat dan memonitor track/jejak pesananannya sudah sampai tahapan mana. Tahapan ini dapat dilihat pada gambar 5 halaman activity produksi;

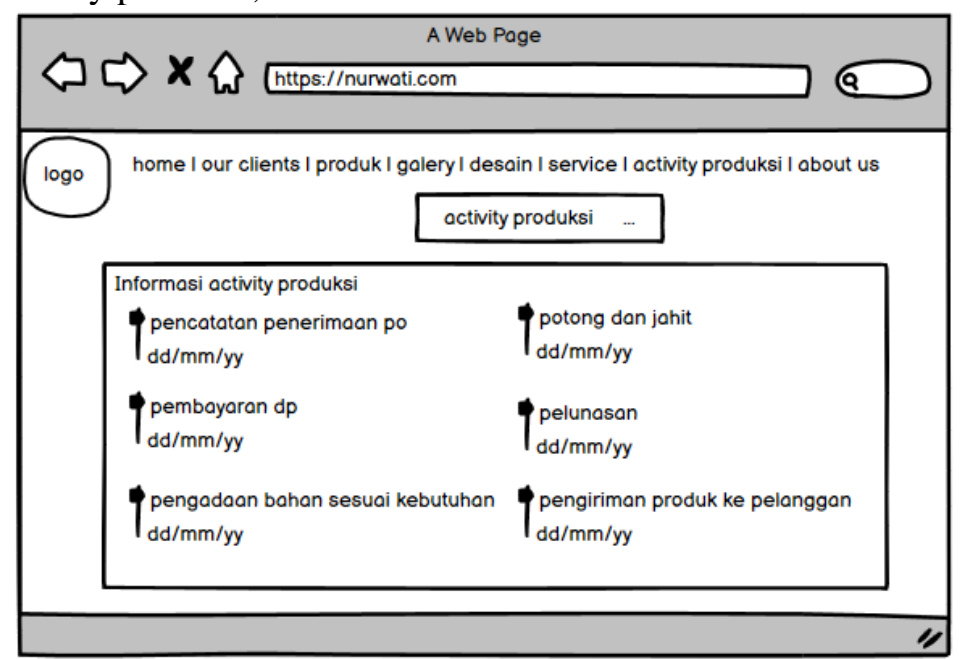

\subsubsection{Halaman service}

Gambar 5 halaman activity produksi

Pada halaman service di protype web Mutiara Seragam online ini berisi informasi service yang diberikan ke pelanggan yaitu diskon pengiriman ke seluruh Indonesia, kemudahan komplain barang dengan penanganan yang baik dan cepat artinya komplain barang ditangani setelah barang sampai di toko kami dan dikirim kembali barang yang sesuai pesanan dengan konfirmasi kembali apakah barang sudah sesuai dengan pesanan atau belum dan ongkos kirim kembali ke palanggan ditanggung pihak Mutiara Seragam online. Kemudian informasi kemudahan konsutasi kepada pelanggan misalnya mengenai jenis bahan yang digunakan panas atau tidak saat digunakan. Informasi selanjutnya yang diberikan pada menu service adalah memberikan dafta harga yang terbaru kepada pelanggan dengan memperbaharui website secara periodik. Halaman service dapat dilihat pada gambar 6 dibawah ini;

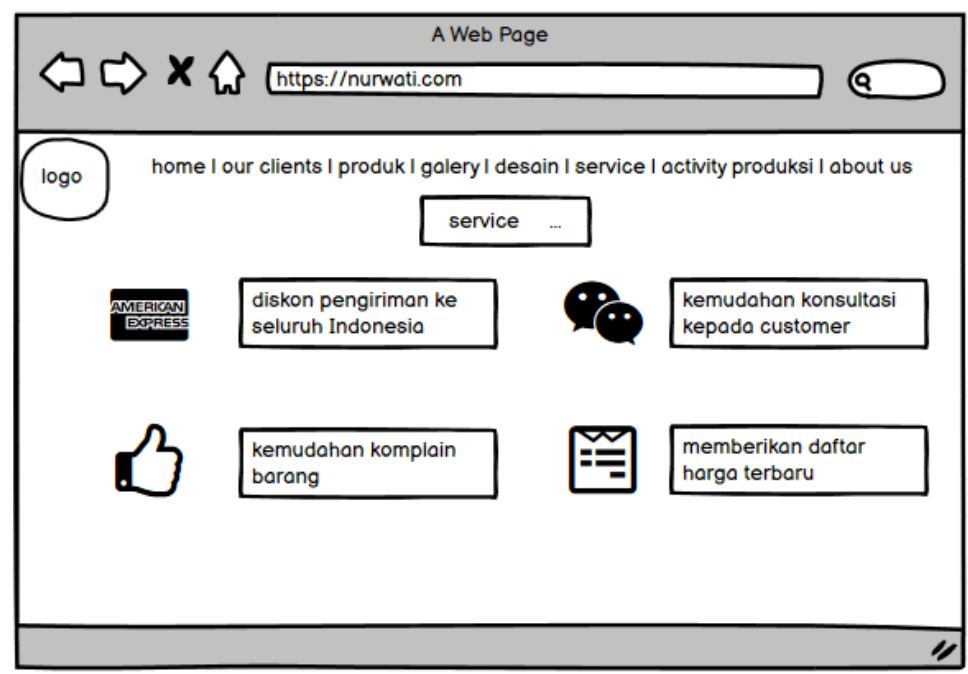

Gambar 6 halaman service 


\section{KESIMPULAN}

Dengan Business Model Canvas ini pemilik Mutiara Seragam dapat menemukan kelebihan dan kekurangan pada bisnisnya. Value atau nilai tambah pada website yang sudah mengadopsi Business Model Canvas (BMC) yang diberikan adalah customer dapat melihat track/jejak pesanannya pada website sehingga memberikan jaminan pesanan pada halaman activity produksi. Kemudian customer diberikan service untuk kemudahan komplain barang dan informasi harga barang yang terbaru seperti yang terdapat pada halaman service.

\section{SARAN}

Namun demikian penelitian lanjutan perlu dikembangkan dengan menerapkan metode Analitical Hierarchy Proses (AHP) untuk menentukan kriteria yang digunakan pada Business Model Canvas (BMC), metode SWOT untuk menganalisa Business Model Canvas (BMC), metode PIECES untuk menganalisa Business Model Canvas (BMC) dan lain sebagainya.

\section{DAFTAR PUSTAKA}

[1] Ikmah and A. S. Widawati, "Penerapan Ecommerce Untuk Pemasaran Pada Usaha Handycraft," Semin. Has. Pengabdi. Masy., vol. November, no. November, pp. 169-174, 2018.

[2] F. N. Lenti, "Rekayasa Proses Bisnis Pada E-Commerce B2B-B2C Menggunakan Sistem Afiliasi," JIKO (Jurnal Inform. dan Komputer), vol. 2, no. 1, pp. 41-49, 2017, doi: 10.26798/jiko.2017.v2i1.53.

[3] A. Annas, M. T. Jufri, and J. Jusmawati, "Penerapan Business Model Canvas pada ECommerce Toko H5 Jayapura," JSAI (Journal Sci. Appl. Informatics), vol. 4, no. 2, pp. 204 220, 2021, doi: 10.36085/jsai.v4i2.1671.

[4] A. F. Viali, A. Rifin, and I. T. Saptono, "Strategi Pengembangan Bisnis Cargo PT. Garuda Indonesia, Tbk dengan Pendekatan Business Model Canvas," J. Apl. Bisnis dan Manaj., vol. 4, no. 3, pp. 474-485, 2018, doi: 10.17358/jabm.4.3.474.

[5] N. Anggraini, "Analisis Usaha Mikro dengan Pendekatan Business Model Canvas (BMC)," Ekon. dan Bisnis, vol. 6, no. 2, p. 139, 2020, doi: 10.35590/jeb.v6i2.1313.

[6] Y. A. Singgalen, E. Sediyono, and I. Sembiring, "Analisis Bisnis Cenderamata Dan Jasa Perjalanan Wisata Menggunakan Business Model Canvas (Bmc) Dan Metode Pieces," AdBispreneur, vol. 6, no. 2, p. 173, 2021, doi: 10.24198/adbispreneur.v6i2.33663.

[7] A. Guntoro and G. Triyono, "Penerapan E-Commerce Berbasis Content Management System (CMS) Dengan Metode Business Model Canvas (BMC) Pada Konveksi Gamis Tawakal," Idealis, vol. 5, no. 2, pp. 16-22, 2019.

[8] . Hartatik and T. Baroto, "Strategi Pengembangan Bisnis Dengan Metode Business Model Canvas," J. Tek. Ind., vol. 18, no. 2, p. 113, 2017, doi: 10.22219/jtiumm.vol18.no2.113-120.

[9] W. S. Dewobroto, "Penggunaan Business Model Canvas Sebagai Dasar Untuk Menciptakan Alternatif Strategi Bisnis Dan Kelayakan Usaha," J. Tek. Ind., pp. 215-230, 2012, [Online]. Available: https://www.researchgate.net/publication/293651050. 